\title{
Bank ownership structure, regulations and risk-taking: evidence from commercial banks in Pakistan
}

\author{
Sobia Ehsan ${ }^{1}$ \& Attiya Yasmin Javid ${ }^{2}$
}

Received: 16 March 2016 / Accepted: 18 July 2018 / Published online: 27 July 2018

\# ISEG 2018

\begin{abstract}
This paper conducts the first empirical assessment of the theories concerning the influence of ownership structure on bank risk-taking in the presence of regulations in Pakistan. The sample used in this paper comprises a panel data of 26 banks in Pakistan, for the period from 2000 to 2014. The analysis provides evidence that increase in ownership concentration leads to an increase in bank risk-taking. Managerial ownership is associated with high risk-taking at low and high levels of managerial ownership while at intermediate level, managerial ownership has negative impact on bank risk-taking. Different types of ownership of banks in Pakistan have different impact on risk-taking. While government, family and institutional ownership have a positive impact on bank risk-taking, foreign ownership has a negative impact on bank risk-taking. Furthermore, the results show that capital regulations are important in influencing bank risk-taking with regard to higher ownership concentration. The findings of this paper suggest that the relation between bank risk-taking and capital regulations typically depends on the type of ownership.
\end{abstract}

Keywords Corporate governance $\cdot$ Banks $\cdot$ Ownership structure $\cdot$ Risk $\cdot$ Regulation

JEL classification $\mathrm{G} 21 \cdot \mathrm{G} 28 \cdot \mathrm{G} 32 \cdot \mathrm{G} 34$

* Sobia Ehsan

sobia.ehsan@nbs.nust.edu.pk

Attiya Yasmin Javid

attiyajaved@gmail.com

1 NUST Business School, National University of Sciences and Technology (NUST), Islamabad H-12, Pakistan

2 Department of Economics, Pakistan Institute of Development Economics (PIDE), Islamabad, Pakistan 